\title{
Chemical Composition of Selected Beetroot Juices in Relation to Beetroot Production System and Processing Technology
}

\section{Renata KAZIMIERCZAK*, Agata SIŁAKIEWICZ, Ewelina HALLMANN, Dominika ŚREDNICKA-TOBER, Ewa REMBIAŁKOWSKA}

\author{
Warsaw University of Life Sciences WULS - SGGW, Faculty of Human Nutrition and Consumer Sciences, Department of Functional Food, \\ Ecological Food and Commodities, 159c Nowoursynowska Street,02-776 Warsaw, Poland; renata_kazimierczak@sggw.pl (*corresponding \\ author); agatka0411@wp.pl; ewelina_hallmann@sggw.pl; dominika_srednicka_tober@sggw.pl; ewa_rembialkowska@sggw.pl
}

\begin{abstract}
Market offer of vegetable juices in Europe is growing, and the vegetable species and processing technologies used become more diversified resulting in a large range of juice types. At the same time consumers look for natural and safe products with pro-health properties. The aim of this study was to evaluate the nutritional composition of selected juices based on beetroots coming from different agricultural systems and processed according to different technologies. Research material consisted of conventional and organic juices marketed in Poland, in that pure pressed juices, fermented juice and juices from concentrate, pure and combined with apple or lemon juice. The concentration of vitamin C, organic acids, total and reducing sugars, phenolic acids, flavonoids and betalains has been determined in the juices. All beetroot juices were abundant in betalains, with higher concentrations of these compounds found in pure beetroot juices when compared to juices combined with apple or lemon. Highest concentration of betanin-3-O-glucoside was found in pure conventional juice from concentrate, while highest betanidin content was found in pure organic fermented juice. Highest vitamin $\mathrm{C}$ contents were found in pressed organic juices combined with apple and lemon. All juices were abundant in polyphenols, mainly phenolic acids, with highest concentrations of these antioxidants found in conventional pure pressed juice. The study shows that beetroot juices, independently on the beetroot processing technology and agricultural production system, are very valuable products due to the presence of numerous bioactive compounds, especially betalains, in their composition. Therefore beetroot juice consumption should be promoted among consumers.
\end{abstract}

Keywords: beetroot juice, betalains, betanidin, betanin, organic production, phenolic compounds

\section{Introduction}

Vegetables and fruit have an important role in the human diet, and increasing of their consumption is recommended by $\mathrm{WHO} / \mathrm{FAO}$ and by nutritional experts around the world (WHO, 2003). Sufficient daily consumption of these products could help prevent major diseases, such as cardiovascular diseases and certain cancers (Key, 2011; Wang et al., 2014). A very important group of products in this context are the processed fruit and vegetables, and vegetable juices among them. The market offer and the availability of these products are getting wider (AIJN Liquid Fruit Market Report, 2015). These allow both to expand the consumption of vegetables, and at the same time to enlarge the intake of their bioactive components during the year. Therefore, nutritionists recommend increasing consumption of vegetable juices instead of replacing natural products with synthetic vitamin-mineral supplements (Liu, 2013). Drinking vegetable juice is one of the ways to increase a dose of essential microelements, vitamins and other antioxidants as well as fiber delivered to the organism (Groele, 2010). Vegetable juices are more easily assimilated in an organism than fresh vegetables, as the squeezing process destroys the fiber structure and releases bound phytonutrients (Rakin et al., 2004). Market offer of vegetable juices in Poland is growing, and the vegetable species, as well as the processing technologies used, become more diversified, resulting in a large range of juice types (Wołosiak and Miłosz, 2012).

Beetroot is one of the valuable vegetables in terms of nutritional value and is increasingly used for juice production. Poland is the largest EU producer of beetroots, with the share of beetroots in the general vegetable harvests reaching nearly $67 \%$ (Eurostat, 2016). In recent years, with the increase in 
492

consumer income, the average yearly consumption of fresh beetroots in Poland decreased from $4.5 \mathrm{~kg}$ to $2.5 \mathrm{~kg}$ per capita, partly in favour of more expensive, imported fruit and vegetables, but also in favour of processed and semi-processed vegetable products. This is most evident in big cities where processed and semi-processed foods, allowing for quick and easy preparation of meals, gain in popularity and where their assortment is constantly growing (Strojewska, 2015).

Owning to high concentrations of minerals, vitamins, flavonoids, phenolic acids, organic acids, sugars, essential oils and dietary fiber, but especially betalains, beetroot has an important role in the human diet (Bogacz, 2010; Petek et al., 2012). From a chemical point of view, betalains are ammonium conjugates of betalamic acid with cyclo-DOPA (betacyanins) and aminoacids or amines (betaxanthins). They can be found in seeds and flowers of plants of most families of the Caryophyllales as well as in fruit of Opuntia ficus-indica and Hylocereus polyrhizus (Strack et al., 2003; Moreno et al., 2008). However, in Europe, the main natural source of betalains (particularly betacyanins) in the human diet is beetroots (Moreno et al., 2008).

Betacyanins rank among water-soluble pigments. Their stability is low, particularly during heating and storage. Therefore, next to the usually used thermal preservation methods, lactic acid fermentation, both spontaneous and with the use of starter bacteria cultures can be an alternative method of preservation of the beetroot juices squished under high pressure. During lactic acid fermentation of beetroot red pigments are partially recovered, due to the decrease in $\mathrm{pH}$ to approximately 4.0. The beetroot juice pigments are optimally stable in an acidic environment (Klewicka et al., 2009). Lactic acid fermentation of vegetables is a common practice to improve shelf life of foods, but also to maintain and improve their nutritional and sensory features (Di Cagno et al., 2013). A great number of lactic acid bacteria were isolated from a variety of traditional naturally fermented foods (Anandharaj and Sivasankari, 2013). Availability of certain nutrients such as minerals, vitamins, as well as acidic nature of vegetables, provides a good medium for lactic acid bacteria. With the success and popularity of sauerkraut, fermentation of many other vegetables, such as e.g. cucumbers, cauliflower, turnips, radishes, celery, carrots and beetroots is gaining in popularity in many countries (Swain et al., 2014).

Vegetable as well as fruit juices are commonly clarified during processing in order to avoid undesirable turbidity, haze, and sediments in the final products. However nowadays there is a rising demand for fruit and vegetable juices with the original characteristics of the fresh products (Hongvaleerata et al., 2008). Therefore such a demand leads to a search for new technologies that are able to improve the quality of the juices. At the same time consumers more often search for freshly pressed juices, which are richer in pectin and bioactive substances coming from raw vegetables, than for clarified products. The turbidity of pressed juices is the result of suspended pectin particles stemming from the plant cell walls, and other disrupted cell materials (Pinelo et al., 2010).

In recent years, the quality of food from organic and conventional farming is a frequent subject of research (Rembiałkowska, 2007; Brandt et al., 2011; Hunter et al., 2011; Barański et al., 2014). Most of the studies indicate higher quality of raw materials from organic farming compared to their conventional counterparts. The differences concern mainly higher sensory quality of organic fruits and vegetables, as well as the higher content of polyphenolic compounds and vitamins in organic agricultural crops compared to conventional ones (Asami et al., 2003; Bavec et al., 2010; Hallmann and Rembiałkowska, 2012; ŚrednickaTober et al., 2013; Kazimierczak et al., 2014). This is mainly due to different fertilization and crop protection regimes used in organic and conventional production systems. The use of mineral fertilizers, especially nitrogen, in conventional farming stimulates high biomass production by plants. This can lead to disruption of other processes in plants, resulting in poorer chemical composition of the plant materials (Heeb et al., 2006; Bloksma et al., 2007). The organic production system, based on organic fertilization, generally favours the synthesis of higher amounts of antioxidant substances in plants. Therefore it can be assumed that the preserves and juices obtained from organic vegetables are richer in these pro-health components.

The aim of this study was to evaluate the nutritional composition (i.e. concentration of nutrients and bioactive substances, especially betalains) of selected beetroot juices available in the retail sales in Poland. The tested samples included conventional and certified organic products, in that pure pressed juices, fermented juice and juices from concentrate, pure and combined with apple or lemon juice.

\section{Materials and Methods}

\section{Research material}

The research was carried out in 2015 in the Warsaw University of Life Sciences (Poland). Research material consisted of six commercial beetroot juices available on the Polish market. Three of them were produced from organic certified beetroots or beetroots combined with apple and lemon, according to organic farming and processing standards (ORG-L - pressed combined with lemon, ORG-A - pressed combined with apple, ORG-B - pressed fermented pure beetroot juice) and three from conventional raw materials (CONV-B - pressed pure beetroot juice, CONV-A - pressed combined with apple and CONV-CB - pure beetroot juice from concentrate). Organic juices were purchased in specialized organic shop, while conventional ones - in the conventional supermarket. All information about the production system, composition and processing of the juices provided by the juice producers are presented in Table 1.

\section{Chemicalanalyses}

Beetroot juice samples were analysed for dry matter content, vitamin $\mathrm{C}$, organic acids, total and reducing sugars, polyphenols (flavonoids and phenolic acids) and betalains. All the analyses were carried out in the analytical laboratory of the Faculty of Human Nutrition and Consumer Science, Warsaw University of Life Sciences, using validated protocols and methods.

Dry matter content was determined using gravimetric method according to the Polish standard (PN-EN 12145:2001).

Vitamin C (L-ascorbic acid) content was determined using a spectrophotometric method according to the relevant Polish standard (PN-A-04019:1998). The method involves the oxidation of L-ascorbic acid to dehydroascorbic acid in the 
acidic environment using 2,6-Dichlorofenoloindofenol. This dye is reduced to the colourless form and at $\mathrm{pH} 4.2$ is pink; the reaction proceeds quantitatively. The weighted fresh beetroot juice samples were extracted in $2 \%$ oxalic acid. The solution was filtered. The filtrate was collected and then the acetate buffer $(\mathrm{pH} 4.0)$ and xylene were added to the sample. Organic layers were separated and upper layer was transferred to spectrometric cuvette. The light absorbance was measured with wavelength of $500 \mathrm{~nm}$. The result was read from the standard curve.

Total acidity was determined according to the relevant Polish standard (PN-EN 12147:2000) based on the neutralization of the total content of acids present in the solution. Water solution of fresh juice sample was titrated with sodium hydroxide until the $\mathrm{pH}$ reached 8.0. Total acidity is converted into a corresponding acid, in this case lactic acid. The result was calculated using a formula described in the standard (PN-EN 12147:2000).

Total sugars and reducing sugars content was determined according to the Luff-Schoorl method (Fortuna et al., 2003). A fresh beetroot juice sample $(2 \mathrm{ml})$ was placed in a beaker, next mixed with $100 \mathrm{ml}$ of distilled water. The beaker's content was transferred to a measuring flask. $5 \mathrm{ml}$ of Carrez I and Carrez II liquids were added, mixed and filled with distilled water. The content of the flask was filtered into a conical flask. The filtrate was taken and then $5 \mathrm{ml}$ of concentrated $\mathrm{HCl}$ was added. Next step was the acid hydrolysis in a hot $\left(68^{\circ} \mathrm{C}\right)$ water bath. $15 \mathrm{ml}$ of $\mathrm{NaOH}$ was added to neutralize the sample. The content of the flask was transferred to a measuring flask and filled with distilled water. The extract was collected from the flask and 25 $\mathrm{ml}$ of Luff liquid was added. The sample was heated (in a flask with reflux condenser) until it came to the boil. Then $10 \mathrm{ml}$ of $30 \% \mathrm{KI}, 25 \mathrm{ml}$ of $25 \% \mathrm{H}_{2} \mathrm{SO}_{4}$, and a few drops of starch were added to the sample. $\mathrm{Na}_{2} \mathrm{~S}_{2} \mathrm{O}_{3}$ was titrated until having obtained the white colour of the solution. At the same time, a blank test was performed without the addition of the filtrate. The amount of the sodium thiosulfate used was subtracted from the value of the blank test and the sugar content from the sugar table enclosed to the methodology was read out.

The content of polyphenols (flavonoids and phenolic acids) in beetroot juices was determined by HPLC method, with identification of individual phenolic compounds according to the Fluca and Sigma Aldrich standards with a purity of $99.5 \%$ (Shimazu equipment, USA Manufacturing Inc, USA: two pump LC-20AD, controller CBM-20A, column oven SIL-20AC, spectrometer UV/Vis SPD-20 AV) (Hallmann, 2012). Weighted amounts of beetroot juice samples were put into the plastic test tubes, then $1 \mathrm{ml}$ of methanol with $1 \%$ ascorbic acid were added, mixed thoroughly by vortex and incubated in an ultrasonic bath $(20 \mathrm{~min}$ at $20^{\circ} \mathrm{C}$ ). Then the samples were centrifuged at the speed of $3,920 \times$ g. From the test tube $1 \mathrm{ml}$ of extract was collected and re-centrifuged at the speed of $22,579 \times \mathrm{g}$. The amount of 500 $\mu \mathrm{l}$ of extract was taken into HPLC vials and analysed. To analyse the phenolic compounds Synergi Fusion-RP 80i column $(250 \times 4.60 \mathrm{~mm})$ was used. The gradient flow was applied along with two mobile phases - acetonitrile/deionized water (55\% and 10\%), $\mathrm{pH} 3.00$. Time of the analysis: $36 \mathrm{~min}$, flow: $1 \mathrm{ml} \mathrm{min}^{-1}$, wavelength: 280-370 nm. HPLC chromatogram showing a profile of polyphenols in the tested beetroot juice is presented on Fig. 1 .

The concentration of betalains in the samples was determined by HPLC method (Slatnar et al., 2015) (Shimazu equipment described above). Betacyanins (betanin-5-Oglucoside and betanidin) were identified based on Fluka standards with a purity of $85 \%$. Samples of beetroot juice were poured into plastic tubes with $80 \%$ ethanol, next mixed thoroughly by vortex and incubated in an ultrasonic bath (at $30^{\circ} \mathrm{C}$, in darkness). Then the samples were centrifuged at the speed of $3,920 \times$ g. $2.5 \mathrm{ml}$ of supernatant were taken from every plastic tube, next $10 \mathrm{n} \mathrm{HCl}$ was added and topped up to $10 \mathrm{ml}$ with ethanol. The samples were kept in the fridge for $10 \mathrm{~min}$, next $1 \mathrm{ml}$ of extract was taken up to HPLC vial and analysed. Betacyanins (betanin-5-O-glucoside and betanidin) have been identified on the basis of standards of Fluca with a purity of $85 \%$. The column Synergi Fusion-RP 80i $(250 \times 4.60 \mathrm{~mm})$ (Shimazu) has been used. The isocratic flow was applied along with one phase: $5 \%$ acetic acid, methanol and acetonitrile (70: $10: 20 \mathrm{v} / \mathrm{v})$. Time of the analysis: $12 \mathrm{~min}$, flow: $1 \mathrm{ml} \mathrm{min}^{-1}$, wavelength: $530-540 \mathrm{~nm}$. HPLC chromatogram showing a profile of betalains in the tested beetroot juice is presented on Fig. 2.

\section{Statistical procedures}

Three independent replicates of each beetroot juice were analyzed. The results are presented as mean \pm standard deviation (SD). Using a Statgraphics 5.1. software (StatPoint Technologies, Inc, Warrenton, Virginia, USA), the data were subjected to a one-way analysis of variance ANOVA, followed by a parametric post-hoc Tukey's test $(\alpha=0.05)$. The $\mathrm{p}$-values are given in the tables; if the result of the analysis was not statistically significant it was designated as ' $n$ '.

\section{Results and Discussion}

The results on concentration of the analysed compounds in the beetroot juice samples are presented in Tables $2-4$ and on Figure 3.

\section{Betalains}

All beetroot juices were abundant in betalains, however, individual products differed significantly with regard to the concentrations of these chemical compounds. Betanin-3-Oglucoside concentrations ranged between 156.45 and 532.42

Table 1. Production system, composition and processing technology of beetroot juices selected for the study

\begin{tabular}{ccccc}
\hline Symbol & Production system & Beetroots $(\%)$ & Fruit $(\%)$ & Processing \\
\hline ORG-L & Organic & 98 & 2\% lemon juice & Pressed, pasteurized \\
ORG-A & Organic & 70 & $30 \%$ apple juice & Pressed, pasteurized \\
ORG-B & Organic & 100 & - & Pressed, lacto-fermented*, pasteurized \\
CONV-B & Conventional & 100 & $50 \%$ apple juice & Pressed, pasteurized \\
CONV-A & Conventional & 50 & - & Pressed, pasteurized \\
CONV-CB & Conventional & 100 & & From concentrate, pasteurized \\
\hline Note: ${ }^{*}$ Natural, spontaneous lactic acid fermentation & &
\end{tabular}


494

$\mathrm{mg} 100 \mathrm{~g}^{-1}$, while betanidin concentrations between 16.75 and

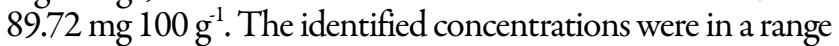
reported in previously published studies (Czyżowska et al., 2006; Szopińska and Gawęda, 2013; Kazimierczak et al., 2014). Higher concentrations of betalains were found in pure beetroot juices when compared to juices combined with other components (apple, lemon). The highest concentration of betanin-3-O-glucoside was found in CONV-CB conventional pure juice from concentrate (higher compared to both pure pressed conventional and the organic juice). Different trend was observed for betanidin. ORG-B and CONV-CB juices were richest in this bioactive compound (Fig. 3). On average, conventionally produced juices contained significantly more betanin-3-O-glucoside than organic ones. In contrast, organic juices, on average, were richer in betanidin. However, it should be pointed that the differences in formulations and processing methods of tested individual organic and conventional juice samples cause that the observations with regard to production system effects should be interpreted cautiously. Kazimierczak et al. (2014) found a higher content of betanin-3-O-glucoside in organic versus conventional beetroots. However, this was true only for fresh, raw produce, while fermented beetroot juices contained similar levels of betanin-3-O-glucoside, independently on the beetroot cultivation system (organic or conventional). As shown by Sakuta et al. (1987), increasing soil nitrogen concentration resulted in higher betacyanin accumulation in the American plant Phytolacca americana L. It is so because betalains (including betacyanins) belong to nitrogen-containing colorants (Moreno et al., 2008; Petek et al., 2012). Brandt and Mølgaard (2001) explained that in growing environments rich in readily assimilable nitrogen, i.e. conventional systems, metabolism of plants changes in the direction of intensive production of nitrogen-containing compounds such as proteins and others.

\section{Vitamin Cand organic acids}

Vitamin C and organic acids contents (Table 2) were found to significantly differ between the tested juice variants. Vitamin C concentrations ranged between 4.43 and $20.36 \mathrm{mg}$ $100 \mathrm{~g}^{-1}$, while organic acids between 0.34 and $0.81 \mathrm{mg} 100 \mathrm{~g}^{-1}$.

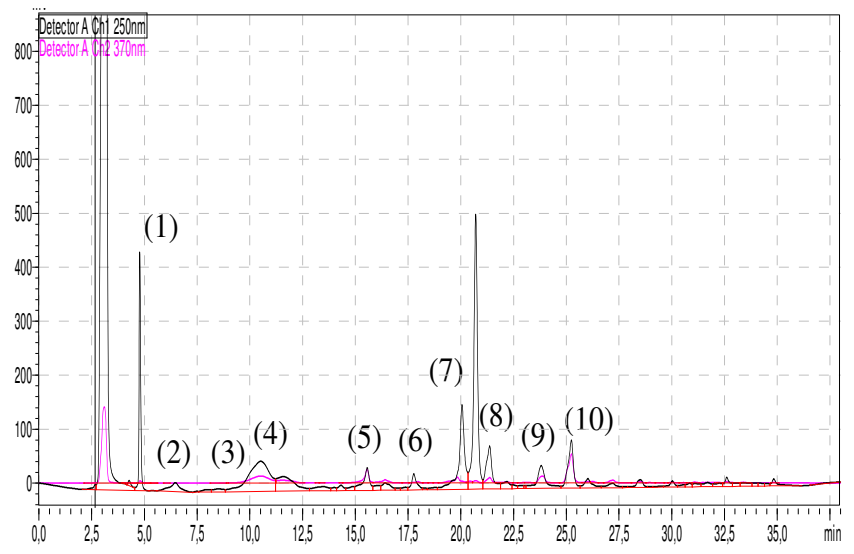

Fig. 1. Chromatographic profile of polyphenols in beetroot juice: (1) gallic acid; (2) chlorogenic acid; (3) caffeic acid; (4) ferulic acid; (5) rutinoside-3-O-quercetin; (6) glucoside-3-Oquercetin; (7) myricetin; (8) luteolin; (9) quercetin; (10) kaempferol

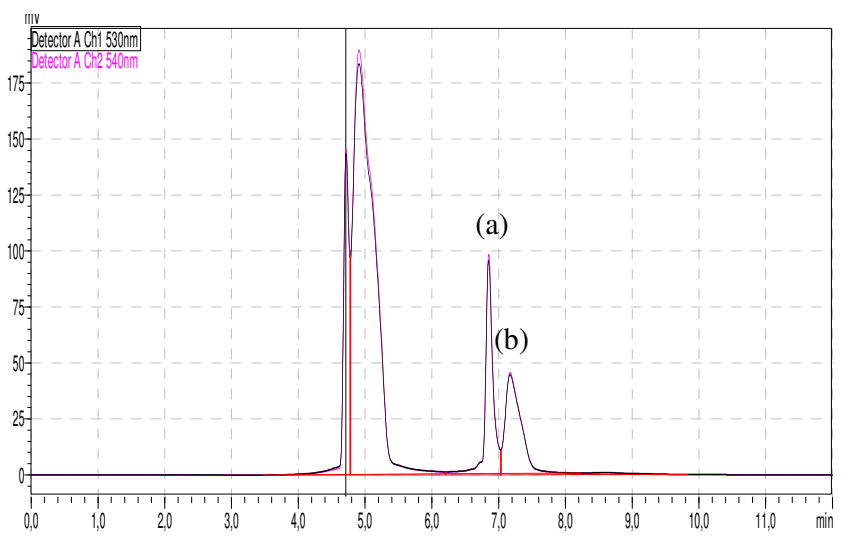

Fig. 2. Chromatographic profile of betalains in beetroot juice: (a) glucoside-5-O-betanine; (b) betanidine

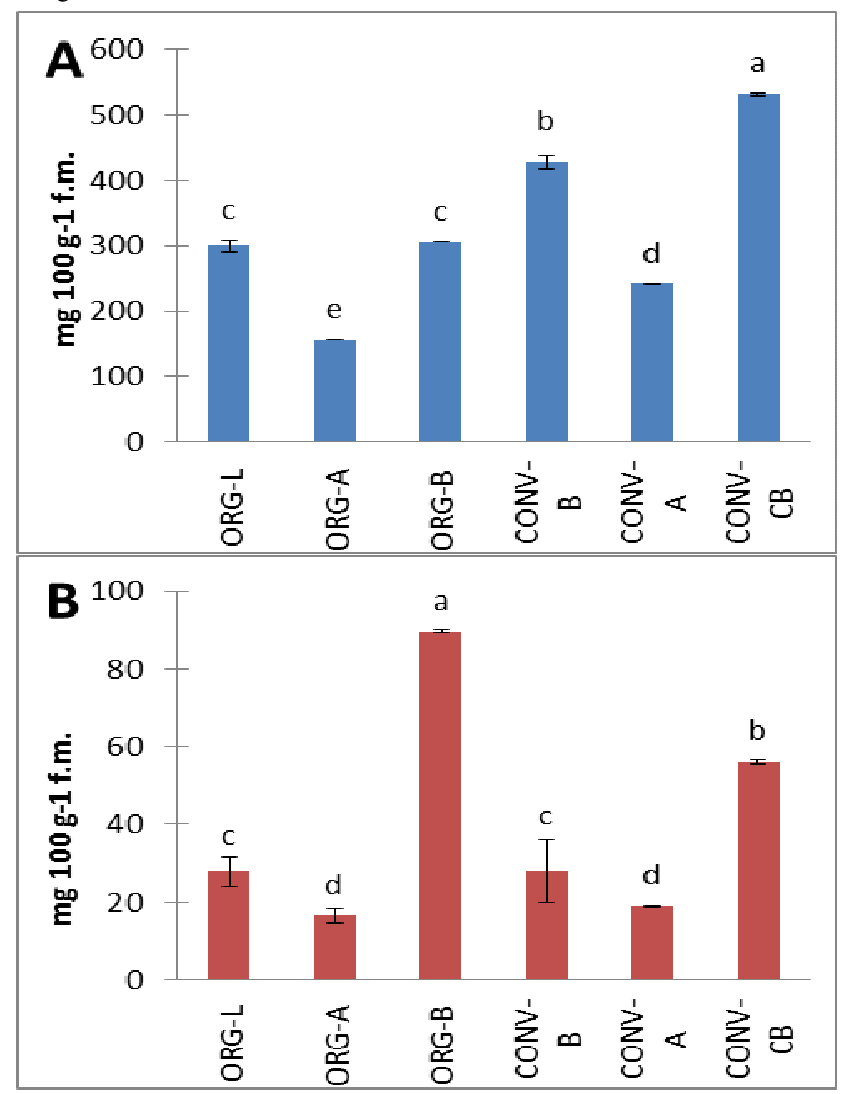

Fig. 3. Betanin-3-O-glucoside (Panel A) and betanidin (Panel B) concentration in selected commercially available organic (ORG) and conventional (CONV) beetroot juices (mean \pm SD). ORG-L organic pressed beetroot juice combined with lemon, ORG-A organic pressed beetroot juice combined with apple, ORG-B organic pressed fermented pure beetroot juice, CONV-B conventional pressed pure beetroot juice, CONV-A - conventional pressed beetroot juice combined with apple, CONV-CB conventional pure beetroot juice from concentrate; means with the same letter are not significantly different at the $5 \%$ level of probability (Tukey's test, $\mathrm{p}<0.05$ )

ORG-B - fermented pure beetroot juice was the most abundant in organic acids. At the same time ORG-L - pressed juice combined with lemon and ORG-A - pressed juice combined with apple contained the highest levels of vitamin $C$, as lemon and apple fruit are richer vitamin $\mathrm{C}$ sources compared 
Table 2. Dry matter, vitamin C, sugars and organic acids content (per $100 \mathrm{~g}$ of fresh matter) in selected commercially available organic (ORG) and conventional $(\mathrm{CONV})$ beetroot juices (mean $\pm \mathrm{SD})$

\begin{tabular}{|c|c|c|c|c|c|}
\hline $\begin{array}{l}\text { Beetroot juice } \\
\text { variants }\end{array}$ & $\begin{array}{c}\text { Dry } \\
\text { matter } \\
\text { (in g) }\end{array}$ & $\begin{array}{c}\text { Vitamin } \\
\text { C } \\
\text { (in } \mathrm{mg} \text { ) }\end{array}$ & $\begin{array}{c}\text { Total } \\
\text { sugars } \\
\text { (ing) }\end{array}$ & $\begin{array}{c}\text { Reducing } \\
\text { sugars } \\
\text { (in g) }\end{array}$ & $\begin{array}{l}\text { Organic } \\
\text { acids } \\
\text { (in g) }\end{array}$ \\
\hline ORG-L & $9.60 \pm 0.33 \mathrm{~b}$ & $18.33 \pm 1.18 \mathrm{a}$ & $5.39 \pm 0.10 c$ & $1.96 \pm 0.26 \mathrm{~d}$ & $0.70 \pm 0.04 b$ \\
\hline ORG-A & $10.40 \pm 0.44 \mathrm{a}$ & $20.36 \pm 2.07 \mathrm{a}$ & $6.53 \pm 0.88 b$ & $5.41 \pm 0.65 \mathrm{~b}$ & $0.72 \pm 0.04 b$ \\
\hline ORG-B & $5.92 \pm 0.29 \mathrm{~d}$ & $13.02 \pm 1.18 \mathrm{~b}$ & $1.73 \pm 0.17 \mathrm{e}$ & $1.21 \pm 0.25 \mathrm{~d}$ & $0.81 \pm 0.02 \mathrm{a}$ \\
\hline CONV-B & $7.63 \pm 0.10 \mathrm{c}$ & $10.75 \pm 0.68 c$ & $3.33 \pm 0.34 d$ & $3.12 \pm 0.30 \mathrm{c}$ & $0.34 \pm 0.01 \mathrm{e}$ \\
\hline CONV-A & $9.42 \pm 0.11 \mathrm{~b}$ & $4.43 \pm 0.39 \mathrm{~d}$ & $7.85 \pm 0.46 a$ & $7.31 \pm 0.71 \mathrm{a}$ & $0.48 \pm 0.03 \mathrm{~d}$ \\
\hline CONV-CB & $10.21 \pm 0.12 \mathrm{a}$ & $15.30 \pm 2.45 \mathrm{~b}$ & $4.05 \pm 0.67 \mathrm{~d}$ & $1.21 \pm 0.16 \mathrm{~d}$ & $0.60 \pm 0.02 \mathrm{c}$ \\
\hline \multicolumn{6}{|l|}{ Average } \\
\hline ORG & $8.64 \pm 2.03$ & $17.24 \pm 3.49 \mathrm{~A}$ & $4.55 \pm 2.16$ & $2.86 \pm 1.92$ & $0.75 \pm 0.06 \mathrm{~A}$ \\
\hline CONV & $9.08 \pm 1.11$ & $10.16 \pm 4.79 \mathrm{~B}$ & $5.08 \pm 2.10$ & $3.88 \pm 2.65$ & $0.47 \pm 0.11 \mathrm{~B}$ \\
\hline \multicolumn{6}{|l|}{ p-value } \\
\hline Production system & ns & 0.0031 & $\mathrm{~ns}$ & $\mathrm{~ns}$ & $<0.0001$ \\
\hline Variant of product & $<0.0001$ & $<0.0001$ & $<0.0001$ & $<0.0001$ & $<0.0001$ \\
\hline
\end{tabular}

Table 3. Flavonoids content (mg $100 \mathrm{~g}-1$ of fresh matter) in selected commercially available organic (ORG) and conventional (CONV) beetroot juices (mean $\pm \mathrm{SD}$ )

\begin{tabular}{cccccccc}
\hline $\begin{array}{c}\text { Beetroot juice } \\
\text { variants }\end{array}$ & Total flavonoids & $\begin{array}{c}\text { Quercetin-3-O- } \\
\text { rutinoside }\end{array}$ & $\begin{array}{c}\text { Quercetin-3-O- } \\
\text { glucoside }\end{array}$ & Myricetin & Luteolin & Quercetin & Kaempferol \\
\hline ORG-L & $2.35 \pm 0.02 \mathrm{a}$ & $0.25 \pm 0.004 \mathrm{a}$ & $0.24 \pm 0.013 \mathrm{a}$ & $0.22 \pm 0.007 \mathrm{~d}$ & $0.15 \pm 0.001 \mathrm{a}$ & $0.14 \pm 0.002 \mathrm{a}$ & $1.35 \pm 0.002 \mathrm{a}$ \\
ORG-A & $2.13 \pm 0.02 \mathrm{c}$ & $0.19 \pm 0.003 \mathrm{c}$ & $0.17 \pm 0.07 \mathrm{~b}$ & $0.20 \pm 0.010 \mathrm{~d}$ & $0.14 \pm 0.003 \mathrm{~b}$ & $0.12 \pm 0.006 \mathrm{ab}$ & $1.31 \pm 0.002 \mathrm{~b}$ \\
ORG-B & $2.24 \pm 0.03 \mathrm{~b}$ & $0.16 \pm 0.003 \mathrm{~d}$ & $0.10 \pm 0.005 \mathrm{c}$ & $0.39 \pm 0.014 \mathrm{~b}$ & $0.14 \pm 0.002 \mathrm{bc}$ & $0.14 \pm 0.025 \mathrm{a}$ & $1.30 \pm 0.003 \mathrm{~b}$ \\
CONV-B & $2.02 \pm 0.01 \mathrm{~d}$ & $0.12 \pm 0.001 \mathrm{e}$ & $0.10 \pm 0.006 \mathrm{c}$ & $0.27 \pm 0.010 \mathrm{c}$ & $0.13 \pm 0.001 \mathrm{~cd}$ & $0.10 \pm 0.002 \mathrm{c}$ & $1.29 \pm 0.001 \mathrm{c}$ \\
CONV-A & $2.22 \pm 0.03 \mathrm{~b}$ & $0.24 \pm 0.014 \mathrm{a}$ & $0.25 \pm 0.011 \mathrm{a}$ & $0.19 \pm 0.003 \mathrm{~d}$ & $0.13 \pm 0.002 \mathrm{~d}$ & $0.12 \pm 0.005 \mathrm{bc}$ & $1.29 \pm 0.003 \mathrm{c}$ \\
\hline CONV-CB & $2.36 \pm 0.03 \mathrm{a}$ & $0.21 \pm 0.013 \mathrm{~b}$ & $0.17 \pm 0.011 \mathrm{~b}$ & $0.44 \pm 0.029 \mathrm{a}$ & $0.14 \pm 0.001 \mathrm{bc}$ & $0.10 \pm 0.001 \mathrm{c}$ & $1.31 \pm 0.007 \mathrm{~b}$ \\
\hline Average & & & & & & \\
ORG & $2.24 \pm 0.09$ & $0.20 \pm 0.036$ & $0.17 \pm 0.060$ & $0.27 \pm 0.091$ & $0.14 \pm 0.004 \mathrm{~A}$ & $0.13 \pm 0.017 \mathrm{~A}$ & $1.32 \pm 0.024 \mathrm{~A}$ \\
CONV & $2.20 \pm 0.15$ & $0.19 \pm 0.054$ & $0.17 \pm 0.065$ & $0.30 \pm 0.109$ & $0.13 \pm 0.003 \mathrm{~B}$ & $0.10 \pm 0.009 \mathrm{~B}$ & $1.30 \pm 0.009 \mathrm{~B}$ \\
\hline $\begin{array}{c}\text { p-value } \\
\text { Production system }\end{array}$ & $\mathrm{ns}$ & $\mathrm{ns}$ & $\mathrm{ns}$ & $\mathrm{ns}$ & 0.0095 & 0.0004 & 0.0135 \\
Variant of product & $<0.0001$ & $<0.0001$ & $<0.0001$ & $<0.0001$ & 0.0001 & 0.0021 & $<0.0001$ \\
\hline N
\end{tabular}

Note: ORG-L - organic pressed beetroot juice combined with lemon, ORG-A - organic pressed beetroot juice combined with apple, ORG-B - organic pressed fermented pure beetroot juice, CONV-B - conventional pressed pure beetroot juice, CONV-A - conventional pressed beetroot juice combined with apple, CONV $\mathrm{CB}$ - conventional pure beetroot juice from concentrate; means in a column followed by the same letter are not significantly different at the $5 \%$ level of probability (Tukey's test, $\mathrm{p}<0.05)$; ns, not statistically significant

to beetroots and significantly enriched the juices in this particular compound. However, surprisingly, CONV-A conventional pressed beetroot juice combined with apple contained the lowest vitamin $\mathrm{C}$ level within all tested juices, despite being mixed with an apple juice.

On average, organic juices contained more vitamin $\mathrm{C}$ and organic acids compared to the conventional ones. This supports many authors findings showing higher contents of vitamin $C$ in organically compared to the conventionally cultivated fruit and vegetables (Brandt et al., 2011) and can be explained by the nitrogen fertilization strategy used in conventional agriculture - increased fertilization tends to reduce the contents of ascorbic acid and other carboncontaining chemical compounds in plants (Stefanelli et al., 2010). The same tendency in terms of vitamin $C$ content was described by Kazimierczak et al. (2014) - fermented beetroot juices from organic production were found to contain significantly more vitamin $\mathrm{C}$ than the conventional ones. However, in the cited study no effect of the production system (organic/conventional) on the content of organic acids in pure fermented beetroot juices has been identified.

\section{Sugars and phenolic compounds}

All the tested beetroot juice samples were a rich source of both total and reducing sugars, but also phenolic compounds. However, individual products differed significantly with regard to the concentrations of these chemicals. Total sugars ranged

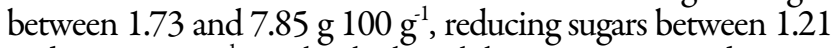

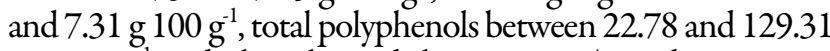
$\mathrm{mg} 100 \mathrm{~g}^{-1}$ and phenolic acids between 20.43 and $127.30 \mathrm{mg}$ $100 \mathrm{~g}^{-1}$. One of the parameters with relatively low variation between the analysed samples were flavonoids, with concentrations ranging from 2.02 to $2.36 \mathrm{mg} 100 \mathrm{~g}^{-1}$. Considering the individual products, the highest concentrations of total sugars, reducing sugars, quercetin-3-Oglucoside and quercetin-3-O-rutinoside were found in CONVA - conventional beetroot juice combined with apple. The highest contents of total polyphenols, phenolic acids, including gallic acid, were found in CONV-B - pure pressed beetroot juice from conventional production. ORG-L - organic beetroot juice combined with lemon was the most abundant in chlorogenic acid and total flavonoids, including most of the identified individual compounds from this group. The highest level of total flavonoids, including myricetin as well as caffeic 
496

Table 4. Polyphenols and phenolic acids content (mg $100 \mathrm{~g}-1$ of fresh matter) in selected commercially available organic (ORG) and conventional $(\mathrm{CONV})$ beetroot juices (mean $\pm \mathrm{SD})$

\begin{tabular}{|c|c|c|c|c|c|c|}
\hline $\begin{array}{l}\text { Beetroot juice } \\
\text { variants }\end{array}$ & $\begin{array}{c}\text { Total } \\
\text { polyphenols }\end{array}$ & $\begin{array}{c}\text { Total phenolic } \\
\text { acids }\end{array}$ & $\begin{array}{c}\text { Gallic } \\
\text { acid }\end{array}$ & $\begin{array}{c}\text { Chlorogenic } \\
\text { acid }\end{array}$ & $\begin{array}{c}\text { Caffeic } \\
\text { acid }\end{array}$ & $\begin{array}{l}\text { Ferulic } \\
\text { acid }\end{array}$ \\
\hline ORG-L & $22.78 \pm 0.88 \mathrm{c}$ & $20.43 \pm 0.90 c$ & $9.32 \pm 0.18 \mathrm{~d}$ & $9.02 \pm 1.07 a$ & $1.08 \pm 0.05 \mathrm{ab}$ & $1.02 \pm 0.04 \mathrm{c}$ \\
\hline ORG-A & $73.58 \pm 3.98 b$ & $71.45 \pm 4.00 \mathrm{~b}$ & $65.50 \pm 4.40 \mathrm{~b}$ & $4.59 \pm 0.24 b$ & $0.93 \pm 0.19 b$ & $0.42 \pm 0.07 \mathrm{~d}$ \\
\hline ORG-B & $37.39 \pm 1.01 \mathrm{c}$ & $35.15 \pm 1.03 c$ & $34.37 \pm 1.03 \mathrm{c}$ & $0.39 \pm 0.07 c$ & $0.22 \pm 0.01 \mathrm{e}$ & $0.17 \pm 0.04 \mathrm{~d}$ \\
\hline CONV-B & $129.31 \pm 19.26 \mathrm{a}$ & $127.30 \pm 19.27 \mathrm{a}$ & $120.37 \pm 19.28 \mathrm{a}$ & $5.11 \pm 0.38 b$ & $0.49 \pm 0.07 \mathrm{~d}$ & $1.34 \pm 0.10 \mathrm{~b}$ \\
\hline CONV-A & $66.28 \pm 10.26 b$ & $64.06 \pm 10.22 b$ & $60.97 \pm 10.30 b$ & $1.32 \pm 0.06 c$ & $0.68 \pm 0.05 c$ & $1.09 \pm 0.09 b c$ \\
\hline CONV-CB & $23.09 \pm 0.83 c$ & $20.73 \pm 0.84 \mathrm{c}$ & $16.44 \pm 0.87 \mathrm{~cd}$ & $0.45 \pm 0.03 c$ & $1.13 \pm 0.03 \mathrm{a}$ & $2.70 \pm 0.33 \mathrm{a}$ \\
\hline \multicolumn{7}{|l|}{ Average } \\
\hline ORG & $44.58 \pm 22.09$ & $42.34 \pm 22.18$ & $36.40 \pm 23.77$ & $4.67 \pm 3.67$ & $0.74 \pm 0.40$ & $0.54 \pm 0.37 \quad B$ \\
\hline $\mathrm{CONV}$ & $72.90 \pm 46.42$ & $70.70 \pm 46.56$ & $65.93 \pm 45.38$ & $2.29 \pm 2.09$ & $0.77 \pm 0.28$ & $1.71 \pm 0.76 \quad \mathrm{~A}$ \\
\hline \multicolumn{7}{|l|}{ p-value } \\
\hline $\begin{array}{l}\text { Production } \\
\text { system }\end{array}$ & ns & ns & ns & ns & ns & 0.0009 \\
\hline $\begin{array}{c}\text { Variant of } \\
\text { product }\end{array}$ & $<0.0001$ & $<0.0001$ & $<0.0001$ & $<0.0001$ & $<0.0001$ & $<0.0001$ \\
\hline
\end{tabular}

Note: ORG-L - organic pressed beetroot juice combined with lemon, ORG-A - organic pressed beetroot juice combined with apple, ORG-B - organic pressed fermented pure beetroot juice, CONV-B - conventional pressed pure beetroot juice, CONV-A - conventional pressed beetroot juice combined with apple, CONV-CB - conventional pure beetroot juice from concentrate; means in a column followed by the same letter are not significantly different at the $5 \%$ level of probability (Tukey's test, $\mathrm{p}<0.05$ ); ns, not statistically significant

and ferulic acids was found in CONV-CB - conventional pure beetroot juice from concentrate. ORG-B - fermented organic beetroot juice was the richest in organic acids and quercetin.

No significant differences were observed between the tested organic and conventional juices (on average) in terms of dry matter content, total and reducing sugars (Table 2), total polyphenols, total flavonoids and total phenolic acids contents (Tables 3, 4). The same was true for most of the identified individual flavonoids (quercetin-3- $O$-rutinoside, quercetin-3$O$-glucoside, myricetin) (Table 3) and most of the individual phenolic acids (gallic, chlorogenic and caffeic acid) (Table 4). However, as already mentioned, the differences in formulations and processing methods of the individual organic and conventional juice samples tested in the study do not allow drawing strong conclusions with regard to the organic vs. conventional production system effects on the chemical composition of juices. Over the last 25 years, a significant number of research studies have compared the concentrations of bioactive compounds (i.e. phenolics) in plant foods coming from organic and conventional production systems (Brandt $e t$ al., 2011). Authors of the most recent and comprehensive meta-analysis summarizing results of more than 300 peerreviewed comparison studies have concluded that organic crops are, on average, characterized by significantly higher concentrations of antioxidants, including various groups of phenolic compounds, lower concentrations of cadmium and at least four times lower incidence of pesticide residues than their conventional counterparts, when compared across regions and agricultural seasons (Barański et al., 2014). On the basis of the above meta-analysis results one could expect health-promoting superiority of organic compared to the conventional foods.

\section{Final considerations and further research}

To summarize, the study shows that beetroot juices are very valuable products due to the presence of numerous bioactive compounds, especially betalains, in their composition. The concentrations of these compounds, however, seem to be affected by both the way of processing and the beetroot agricultural production system, e.g. the organic juice samples tested in the study, on average, showed significantly higher content of vitamin $\mathrm{C}$, organic acids and betanidin, but also luteolin, quercetin and kaempferol in comparison to conventional ones. In contrast, conventionally produced juices had a significantly higher content of ferulic acid and betanin-3$O$-glucoside than their organic counterparts. It is at the same time important to mention that the variation between individual juice samples representing one production system was also high, showing the importance of other factors (i.e. juice processing and formulation) for the tested parameters of chemical composition. Further research, including higher number of tested organic vs. conventional samples and accounting for other relevant factors (not only processing, but also e.g. storage, packing and transport conditions known to affect the quality of processed foods), would be necessary to confirm the findings and/or explain the background of the identified differences (Lee and Kader, 2000; Bloksma et al., 2007).

\section{Conclusions}

Beetroot juices are very valuable products, mainly due to the presence of numerous bioactive compounds (i.e. betalains, flavonoids, phenolic acids and vitamin C) in their composition. Comparison of products processed with the use of different technologies and coming from different (organic / conventional) production systems, did not allow making conclusions about superiority of a particular product. However, the obtained results clearly show that introducing any of the beetroot juices to the consumers' diet can have a great impact on their intake of numerous pro-health compounds. The beetroot juices consumption should therefore be promoted among consumers. Special attention should be paid to organic certified products, which guarantee high standards of production as well as high nutritional and health-oriented value. 


\section{Acknowledgements}

This research received no specific grant from any funding agency in the public, commercial, or not-for-profit sectors.

\section{References}

AIJN European Fruit Juice Association (2015). Liquid Fruit Market Report. Retrieved2016Apr 12 from http://www.aijn.org/files/default/aijn2015report.pdf.

Anandharaj M, Sivasankari B (2013). Isolation of potential probiotic Lactobacillus strains from human milk. International Journal of Research in Pharmacy and Life Sciences 1(1):26-29.

Asami DK, Hong YJ, Barrett DM, Mitchell AE (2003). Comparison of the total phenolic and ascorbic acid content of freeze-dried and air-dried marionberry, strawberry, and corn grown using conventional, organic, and sustainable agricultural practices. Journal of Agricultural and Food Chemistry 51(5):1237-1241.

Barański M, Średnicka-Tober D, Volakakis N, Seal Ch, Sanderson R, Stewart GB, ... Leifert C (2014). Higher antioxidant and lower cadmium concentrations and lower incidence of pesticide residues in organically grown crops: a systematic literature review and meta-analyses, British Journal of Nutrition 112(5):794811.

Bavec M, Turinek M, Grobelnik-Mlakar S, Slatnar A, Bavec F (2010). Influence of industrial and alternative farming systems on contents of sugars, organic acids, total phenolic content, and the antioxidant activity of red beet (Beta vulgaris L. ssp. vulgaris Rote Kugel). Journal of Agricultural and Food Chemistry 58(22):11825-11831.

Bloksma J, Northolt M, Huber M, van der Burgt GJ, van de Vijver L (2007). A new food quality concept based on life processes. In: Cooper J, Niggi U, Leifert C (Eds). Handbook of organic food safety and quality. Woodhead Publishing Limited Cambridge, UK and CRC Press LLC, Florida, USA pp 53-73.

BogaczK(2010). Burak zwyczajny-superwarzywo, [Betavulgaris-the super vegetable]. Przemyst Fermentacyjnyi Owocowo-Warzywny 1:38-39.

Brandt K, Leifert C, Sanderson R, Seal CJ (2011). Agroecosystem management and nutritional quality of plant foods: the case of organic fruits and vegetables. Critical Reviews in PlantSciences30(1-2):177-197.

Brandt K, Mølgaard JP (2001). Organic agriculture: does it enhance or reduce the nutritional value of plant foods? Journal of the Science of Food and Agriculture 81(9):924-931.

Czyżowska A, Klewicka E, Libudzisz Z (2006). The influence of lactic acid fermentation process of red beet juice on the stability of biologically active colorants. European Food Research and Technology 223(1):110-116.

Di Cagno R, Coda R, De Angelis M, Gobbetti M (2013). Exploitation of vegetables and fruits through lactic acid fermentation. Food Microbiology33(1):1-10.

Eurostat (2016). Root crops and plants harvested green from arable land by area. Retrieved 2016 Mar 11 from http://ec.europa.eu/eurostat/web/agriculture/data/main-tables.

Fortuna T, Juszczak L, Sobolewska-Zielińska J (2003). Podstawy analizy żywności. Skrypt do ćwiczen, [The basics of the food analysis. Exercise script]. The Polish Committee for Standardization, Warsaw, Poland.
Groele B (2010). Soki klarowne, naturalnie mętne, przecierowe lub z dodatkiem przecieru, [Clarified juices, naturally turbid juices, juices from puree or with the addition of puree]. Przemyst Fermentacyjny i Owocowo-Warzywny 54(7-8):3.

Hallmann E (2012). The influence of organic and conventional cultivation systems on the nutritional value and content of bioactive compounds in selected tomato types. Journal of the Science of Food and Agriculture 92(14):2840-2848.

Hallmann E, Rembiatkowska E (2012). Characterisation of antioxidant compounds in sweet bell pepper (Capsicum annuum $\mathrm{L}$.) under organic and conventional growing systems. Journal of the Science of Food and Agriculture 92(12):2409-2415.

Heeb A, Lundegardh B, Savage G, Ericsson T (2006). Impact of organic and inorganic fertilizers on yield, taste, and nutritional quality of tomatoes. Journal of Plant Nutrition and Soil Science 169(4):535-541.

Hongvaleerata Ch, Cabralb LMC, Dornierc M, Reynesc M, Ningsanonda $S$ (2008). Concentration of pineapple juice by osmotic evaporation. Journal of FoodEngineering 88(4):548-552.

Hunter D, Foster M, Mcarthur JO, Ojha R, Petocz P, Samman S (2011). Evaluation of the micronutrient composition of plant foods produced by organic and conventional agricultural methods. Critical Reviews in Food Science and Nutrition 51(6):571-582.

Kazimierczak R, Hallmann E, Lipowski J, Drela N, Kowalik A, Püssa T, .... Rembiatkowska E (2014). Beetroot (Beta vulgaris L.) and naturally fermented beetroot juices from organic and conventional production: metabolomics, antioxidant levels and anticancer activity, Journal of the Science of Food and Agriculture 94(13):2618-2629.

Key TJ (2011). Fruit and vegetables and cancer risk. British Journal of Cancer 104(1):6-11.

Klewicka E, Zduńczyk Z, Jumkiewicz J (2009). Effect of lactobacillus fermented beetroot juice on composition and activity of cecal microflora of rats. European Food Research and Technology 229(1):153-157.

Lee SK, Kader AA (2000). Preharvest and postharvest factors influencing vitamin C content of horticultural crops. Postharvest Biology and Technology 20(3):207-220.

Liu RH (2013). Health-promoting components of fruits and vegetables in the diet. Advances in Nutrition 4(3):384392.

Moreno DA, García-Viguera C, Gil IJ (2008). Betalains in the era of global agri-food science, technology and nutritional health. Phytochemistry Reviews 7(2):261-280.

Petek M, Herak Čustić M, Toth N, Slunjski S, Čoga L, Pavlovič I, ... Cvetkovič S (2012). Nitrogen and crude proteins in beetroot (Beta vulgaris var. conditiva) under different fertilization treatments. Notulae Botanicae Horti Agrobotanici Cluj-Napoca 40(2):215-219.

Pinelo M, Zeuner B, Meyer AS (2010). Juice clarification by protease and pectinase treatments indicates new roles of pectin and protein in cherry juice turbidity. Food and Bioproducts Processing 88(2-3):259-265.

Polish Standard PN-A-04019:1998 (1998). Produkty spożywcze Oznaczanie zawartości witaminy C, [Food products. Determination of vitamin C]. The Polish Committee for Standardization, Warsaw, Poland.

Polish Standard PN-EN 12145:2001 (2001). Soki owocowe i warzywne. Oznaczanie catkowitej suchej substancji. Metoda grawimetryczna, 
498

[Fruit and vegetable juices. Determination of dry matter. Gravimetric method]. The Polish Committee for Standardization, Warsaw, Poland.

Polish Standard PN-EN 12147:2000 (2000). Soki owocowe i warzywne.

Oznaczanie kwasowości miareczkowej, [Fruit and vegetable juices. Determination of total acidity]. The Polish Committee for Standardization, Warsaw, Poland.

Rakin M, BarasJ, VukasinovićM, MaksimovićM (2004). The examination of parameters for lactic acid fermentation and nutritive value of fermented juice of beetroot, carrot and brewer's yeast autolysate. Journal of the Serbian Chemical Society 69(8-9):625-634.

Rembialkowska E (2007). Review: Quality of plant products from organic agriculture. Journal of the Science of Food and Agriculture 87(15):27572762.

Sakuta M, Takagi T, Komamine A (1987). Effects of nitrogen source on betacyanin accumulation and growth in suspension cultures of Phytolacca americana. Physiologia Plantarum 71(4):459-463.

Slatnar A, Stampar F, Veberic R, Jakopic J (2015). HPLC-MSn identification of betalain profile of different beetroot (Beta vulgaris L. ssp. vulgaris) parts and cultivars. Journal of Food Science 80(9):1952-1958.

StefanelliD, Goodwin I, Jones R(2010). Minimal nitrogen and water use in horticulture: Effects on quality and content of selected nutrients. Food Research International 43(7):1833-1843.

Strack D, Vogt T, Schliemann W (2003). Recent advances in betalain research. Phytochemistry 62(3):247-269.

Strojewska J (2015). Rynek owoców i warzyw. Produkcja, konsumpcja, handel zagraniczny, [Fruit and vegetables market. Production, consumption, foreign trade]. Agricultural Market Agency Newsletter 3/2015. Retrieved 2016 Apr 2 from http://www.arr.gov.pl/data/400/biuletyn_informacyjny_arr_3_2015. pdf.
Swain MR, Anandharaj M, Ray RC, Rani RP (2014). Fermented fruits and vegetables of Asia: A potential source of probiotics. Biotechnology Research International 1-19.

Szopińska AA, Gawęda M (2013). Comparison of yield and quality of red beets cultivated using conventional, integrated and organic method. Journal of Horticultural Research 21(1):107-114.

Średnicka-Tober D, Barański M, Gromadzka-Ostrowska J, Skwarło-Sońta K, Rembiałkowska E, Hajslova J, ... Leifert C (2013). Effect of crop protection and fertilization regimes used in organic and conventional production systems on feed composition and physiological parameters in rats.Journal of Agricultural and Food Chemistry 61(5):1017-1029.

Wang X, Ouyang Y, Liu J, Zhu M, Zhao G, Bao W, Hu FB (2014). Fruit and vegetable consumption and mortality from all causes, cardiovascular disease, and cancer: systematic review and dose-response meta-analysis of prospective cohort studies. BMJ 349(g4490):1-14.

WHO (2003). Diet, nutrition and the prevention of chronic diseases. Technical Report Series No. 916. World Health Organization. $\begin{array}{lllll}\text { Retrieved } & 2016 & \text { Apr } & 12 & \text { from }\end{array}$ http://apps.who.int/iris/bitstream/10665/42665/1/WHO_TRS_91 6.pdf?ua $=1$.

Wołosiak R, Miłosz K (2012). Porównanie jakości wybranych soków marchwiowych i pomidorowych, [Quality comparison of selected carrot and tomato juices]. Bromatologia i Chemia Toksykologiczna 45(3):711-716. 